\title{
Surgical Resection of a Complex Multiple Scalp AVF without Preoperative Embolization: A Case Report
}

\author{
Preoperatif Embolizasyon Yapmadan Kompleks Çoklu Saçlı Deri AVF \\ Cerrabi Rezeksiyonu: Bir Olgu Sunumu
}

\author{
Bai XUE, Liu YI, You CHAO \\ West China Hospital of Sichuan University, Department of Neurosurgery, Chengdu, China
}

Corresponding Author: You CHAO / E-mail: obutwhy@aliyun.com

\begin{abstract}
Complex multiple arteriovenous fistula (AVF) of the scalp is an extremely rare disease and the traditional treatment is either endovascular embolization or surgical resection with preoperative endovascular embolization. Here, a 34-year-old male with pulsating mass and multiple tortuous vessels in front of the left tragus and scalp who was diagnosed as complex multiple arteriovenous fistula of the scalp is presented. Nearly total surgical resection of the lesion without preoperative intervention was performed. The deformity appearance and the buzzing sound in the patient's left ear were eradicated after operation. Therefore, surgical resection without preoperative embolization is still a promising method to treat complex multiple scalp AVF.
\end{abstract}

KEYWORDS: Arteriovenous fistula, Cirsoid aneurysm, Scalp, Surgical procedure

öz

Saçlı derinin kompleks çoklu arteriyovenöz fistülü (AVF) çok nadir bir hastalıktır ve geleneksel tedavisi endovasküler embolizasyon veya preoperatif endovasküler embolizasyonla birlikte cerrahi rezeksiyondur. Burada saçlı derinin kompleks çoklu arteriyovenöz fistülü tanısı konan, sol tragus önünde çok sayıda kıvrımlı damarı ve pulsasyonlu bir kitlesi bulunan 34 yaşında bir erkeği sunuyoruz. Preoperatif bir girişim yapılmadan lezyonun hemen hemen total rezeksiyonu gerçekleştirildi. Ameliyattan sonra deformite görünümü ve hastanın sol kulağındaki vızıltı sesi ortadan kalktı. Preoperatif embolizasyonsuz cerrahi rezeksiyon kompleks çoklu saçlı deri AVF tedavisinde halen ümit veren bir yöntemdir.

ANAHTAR SÖZCÜKLER: Arteriyovenöz fistül, Sirsoid anevrizma, Saçlı deri, Cerrahi işlem

\section{INTRODUCTION}

Arteriovenous fistula (AVF) of the scalp is a rare disease that was first described by Hunter in 1757 (10). It is commonly divided into two types: congenital (13) and traumatic type $(12,13,18,19,26,28)$. The latter one is the most common type and mainly results from head trauma or iatrogenic reasons such as craniotomy, infusions through scalp veins, and hair transplantation $(1,8,13,24,29)$. The main signs and symptoms of a scalp AVF include pulsating scalp masses, headache, allodynia, hemorrhage, cutaneous necrosis, epilation, and tinnitus $(2,15,31)$. In this paper, a case of a diffuse scalp AVF involving multiple scalp vessels was presented. Its diagnosis and management are extensively discussed with a detailed review of the relevant literature.

\section{CASE REPORT}

A 34-year-old male was admitted because of a pulsating mass in front of his left tragus for 10 years. He had noticed the mass immediately after someone kicked his left temporal region when he was 24 . The mass has grown over the years from the size of a soybean to the size of a big thumb. Many tortuous vessels emerged around the lesion resulting in a Medusa's hair-like deformity. The patient also experienced a continuous buzzing sound in left ear that had caused insomnia in the last 2 years. Physical examination revealed a pulsating serpent-like mass of $3 \mathrm{~cm} \times 12 \mathrm{~cm}$ in size along the course of the left superficial temporal artery accompanied by multiple tortuous vessels (Figure 1A-F). Compression on the proximal end of superficial temporal artery could cause partial shrinkage of the distal mass and decrease in the bruits. Computerized tomography angiography (CTA) (Figure 2A$\mathrm{H})$ and digital subtraction angiography (DSA) (Figure $3 \mathrm{~A}-\mathrm{F}$ ) revealed a complex multiple arteriovenous fistula located in the left scalp and part of the right frontoparietal region. The feeding arteries included bilateral superficial temporal arteries (STA), bilateral supraorbital arteries (SOA), bilateral occipital arteries (OA) and left posterior auricular artery (PAA). The dominant draining vein was the left superficial temporal vein. In addition, there was a dural AVF fed by the left ophthalmic artery.

The patient was operated in the supine position under general anesthesia. A semicircular scalp incision along the 


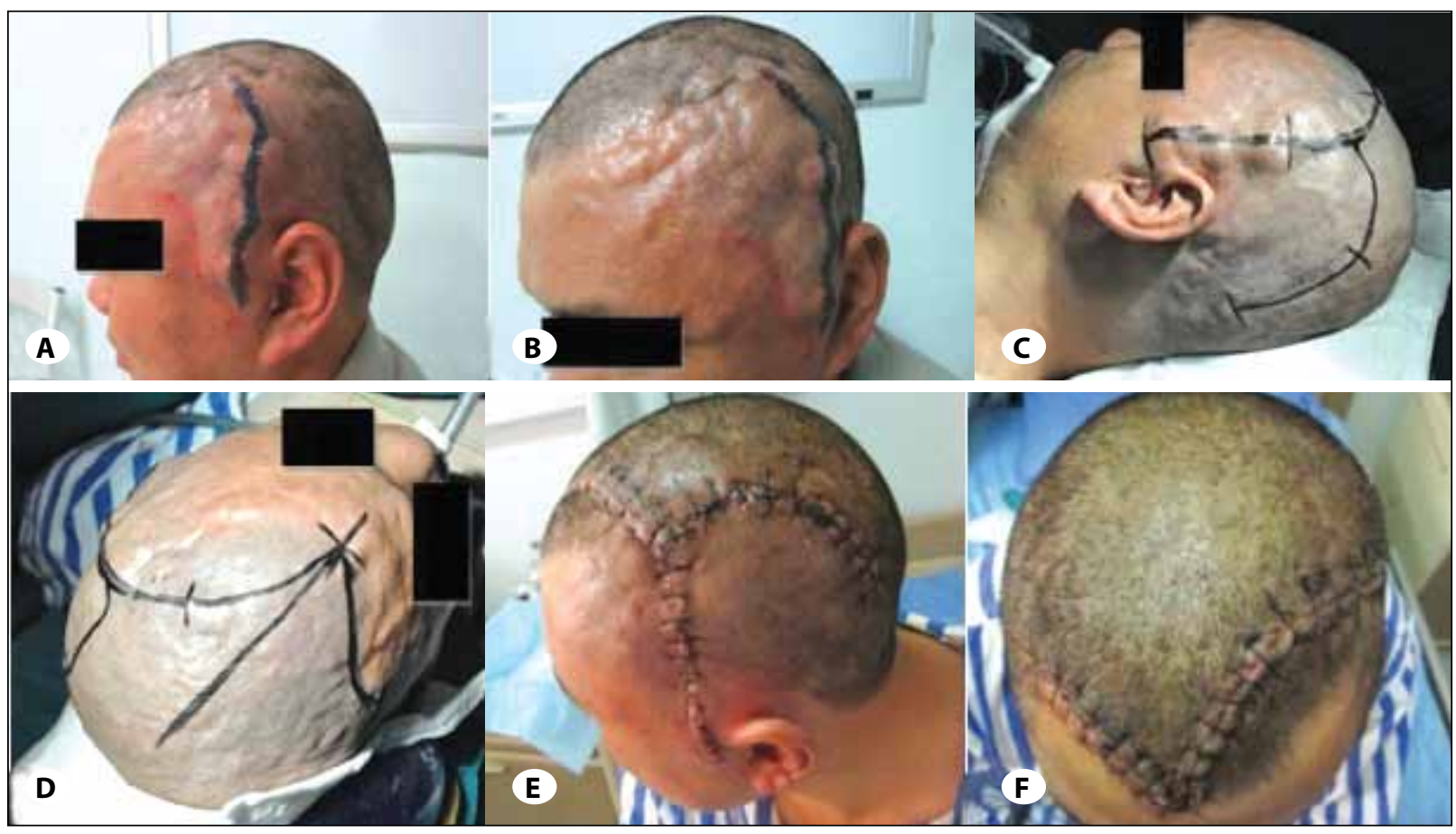

Figure 1: A, B) show the serpent-like mass and extensive tortuous vessels in scalp. C, D) show the well-designed scalp incision. E, F) show the improved appearance without scalp necrosis 10 days after surgery.

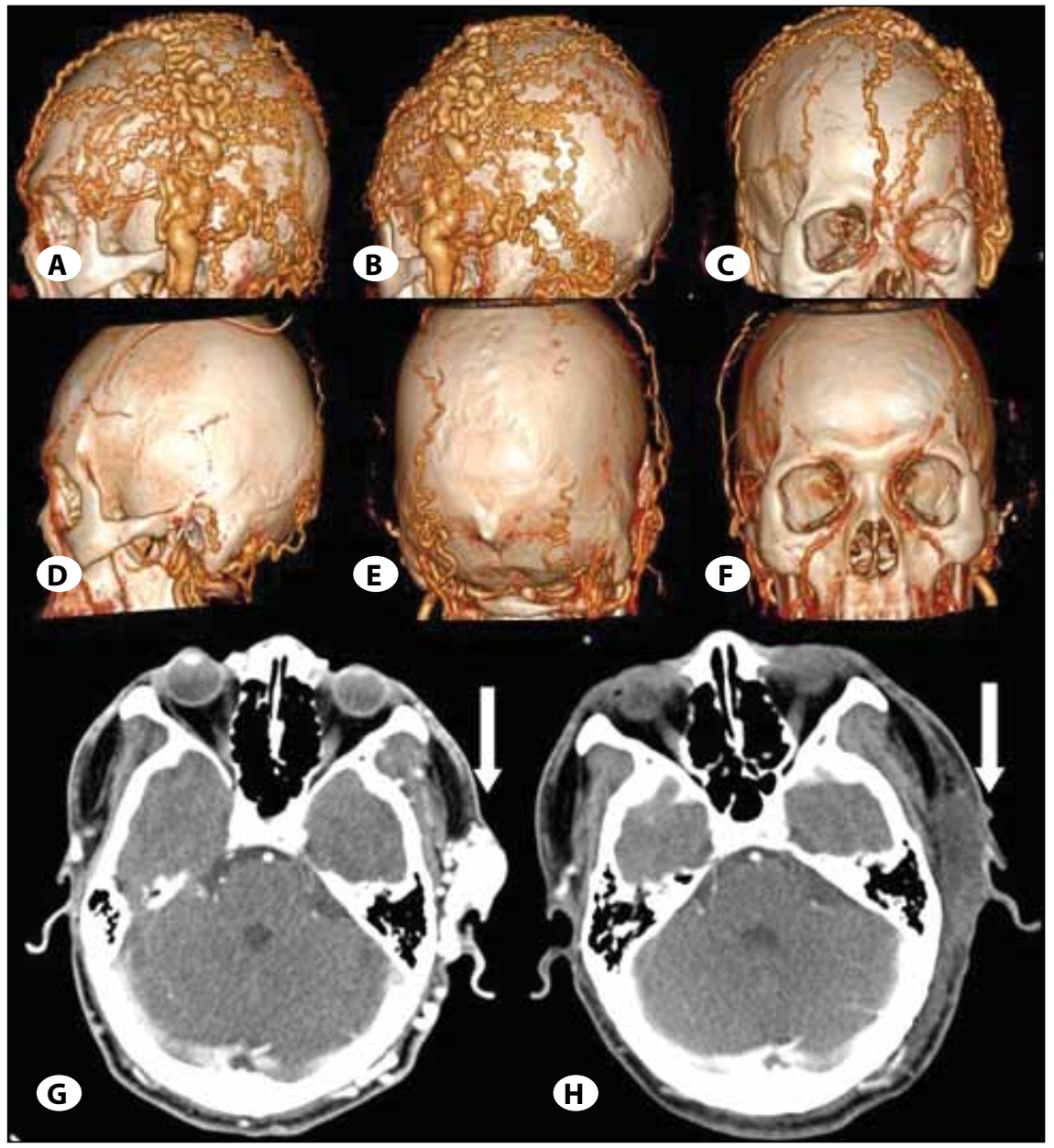

Figure 2: A, B, C, G) CTA shows the angioarchitecture of the AVF. D, E, F, H) CTA performed 2 days after surgery shows nearly total resection of the AVF. (Arrows indicate the left STA). 


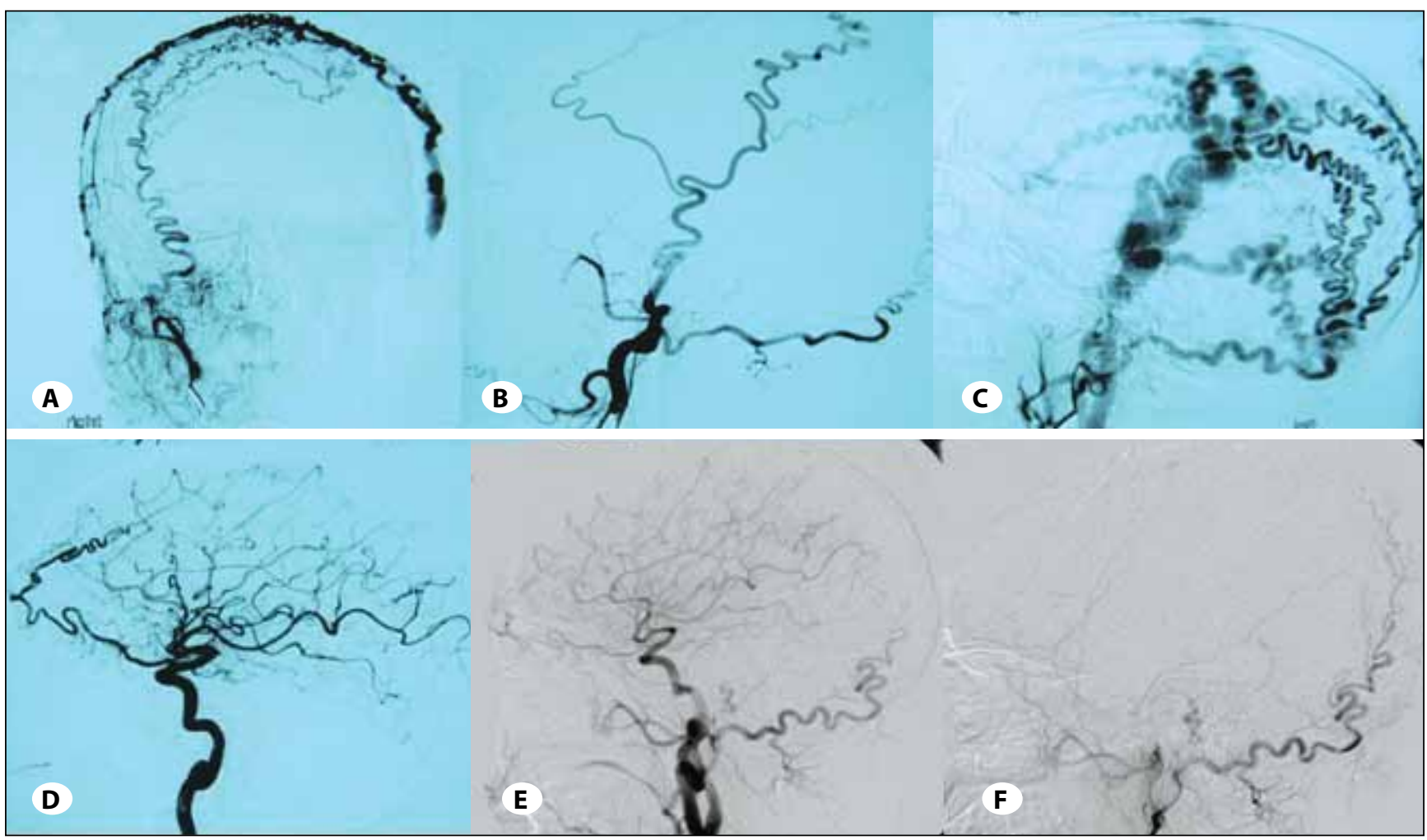

Figure 3: A-D) DSA shows the angioarchitecture of the AVF. E, F) DSA performed 11 days after surgery shows nearly total resection of the AVF except the residual feeding arteries from the OA.

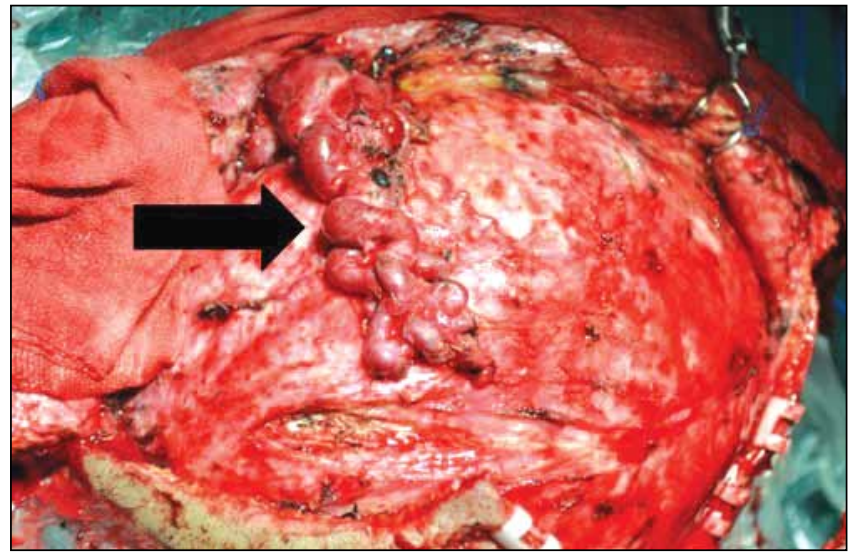

Figure 4: Arrow indicates tortuous dilated draining veins in the left scalp along the course of left STA.

left STA and an adjuvant scalp incision along the left OA were made (Figure 1A-F). When we cut open the scalp, we found abundant huge tortuous dilated venous plexuses located between the periosteum and galea aponeurotica (Figure 4). The feeding arteries ran in the deep region of the draining veins and were relatively smaller than them. We ligated or coagulated and cut the feeding arteries and draining veins. Then, the flap was sutured in the standard fashion (Figure 1AF). The total blood loss was $67 \mathrm{ml}$. Histopathology of the lesion demonstrated an arteriovenous fistula. The patient did not hear any buzzing sound after surgery, and the protuberances in the scalp disappeared (Figure 1A-F). Postoperative CTA and DSA (Figure $2 \mathrm{~A}-\mathrm{H}, 3 \mathrm{~A}-\mathrm{F}$ ) showed nearly total resection of the AVF except the residual feeding arteries from the OA. It was interesting in our case that although we did not deal with the dural AVF because of the patient's rejection, postoperative DSA did not show the lesion any more (Figure $3 A-F)$.

\section{DISCUSSION}

Scalp arteriovenous fistulas are rare lesions that mainly develop due to head trauma. STA is one of the most common vessels involved because of its long and relatively superficial course in the scalp $(17,21)$. Once the STA is injured, an abnormal communication between arteries and veins would appear. This lesion would receive more blood volume from the abundant collaterals in the scalp, resulting in a progressive venous dilation (11). Eventually, the remarkable tortuous subcutaneous vessels can create a severe scalp and facial cosmetic deformity. Some patients may suffer from murmurs, trembling and headache that can be debilitating and annoying. However, this condition is not life-threatening (4).

The diagnosis of a scalp AVF is based on a pulsating mass in the scalp with bruit and thrill, and a typical AVF manifestation in DSA. The indications for the treatment are cosmetic deformity, tinnitus, pain, skin erosion with the possibility of rupture in the lesion, and high-output cardiac failure resulting from arteriovenous shunt. 
Table I: Treatment of Scalp AVFs in the Last 20 Years from the Literature

\begin{tabular}{|c|c|c|c|c|}
\hline & Number of Cases & Cure & $\begin{array}{l}\text { Unsuccessful or } \\
\text { Recurrence }\end{array}$ & Complication \\
\hline Endovascular Embolization & 29 & 26 & 3 & 4 \\
\hline Surgical Resection & 65 & 65 & 0 & 2 \\
\hline $\begin{array}{l}\text { Surgical Resection and } \\
\text { Endovascular Embolization }\end{array}$ & 5 & 5 & 0 & 0 \\
\hline Conservative Treatment & 4 & 0 & 4 & 0 \\
\hline
\end{tabular}

The treatment of a scalp AVF usually includes endovascular embolization by itself or combined with surgical resection (Table I) $(3,5,6,7,9,11-16,19-21,23,25,27,30-34)$. In our reviewed literature, the common treatment of a complex multiple AVF is either endovascular embolization or surgical resection with preoperative endovascular embolization. Embolization is a less aggressive method and consists of injecting a liquid agent or placing a solid emboli at the junction of the feeding artery and the draining vein $(4,33)$. However, Luessenhop found that the risk of recurrence after embolization was high as this method could not deal with all the pericranial vessels (22). Moreover, there are many other complications after embolization such as the pain at the fistula site, tenderness and hyperemia over the skin, necrosis over the lesion, escape of the embolic material to the circulation, and permanent patchy hair loss that may not improve and lead to cosmetic problems $(1,15,17,21)$. Therefore, subsequent surgical removal of the embolic material is necessary in many cases.

Surgical resection of a complex multiple AVF may be difficult regarding the primary closure and scalp necrosis. However it has been proven to be an exact and effective treatment with obvious improvement of deformity, low incidence of complications and recurrence if neurosurgeons make a meticulous plan (11). In view of this, we chose direct resection without preoperative embolization. We designed the incision according to angioarchitecture features provided by CTA and DSA. To avoid torrential hemorrhage, we dissected the huge dilated vessels patiently and carefully as we were cutting the scalp. To ensure a complete resection, both the ligation of proximal feeding arteries (21) and the resection of the draining veins were very important. During surgery, we also found numerous small tortuous draining veins and feeding arteries in the subcutaneous layer of the scalp and these were not detected by preoperative CTA or DSA. The involved vessels were too diffuse in the left scalp, and we therefore separated and ligated these abnormal small vessels instead of resecting the overlying skin and flap transposition or skin-grafting. Eventually we sutured the flap in situ. Our experience is that dissection of these superficial vessels should not be too close to the skin to avoid buttonholes to deface the appearance. The vasospasm after surgery is another problem that may lead to the false assumption that a total surgical resection has been done (4). Angiography should therefore be performed a few days and even months after surgery to assess the resection rate and recurrence.

\section{CONCLUSION}

Although AVF is not a life-threatening lesion, treatment could help patients to improve their quality of life. Surgical resection without preoperative embolization is still a promising method to treat complex multiple scalp AVF. Careful identification, dissection and complete resection of the abnormal vessels are the key points for the cure of the complex multiple scalp AVF.

\section{REFERENCES}

1. Amlashi SF, Riffaud L, Morandi X: Arteriovenous fistula of the superficial temporal artery: An exceptional complication of the pterional approach. J Neurol Neurosurg Psychiatry 75:1077-1078, 2004

2. Baysefer A, Gönül E, Erdoğan $E$, Akay $K M$, Bedük $A$, Seber N: Cirsoid aneurysms of the scalp. Eur J Plast Surg 21:48-50, 1998

3. Burrus TM, Miller GM, Flynn LP, Fulgham JR, Lanzino G: Neurolmages. Symptomatic left temporal arteriovenous traumatic fistula. Neurology 73:570, 2009

4. Calwell El, McKinstry CS, Kendrick RW: Arteriovenous fistula after temporomandibular arthroscopy. Br J Oral Maxillofac Surg 37:127-128, 1999

5. Corr PD: Cirsoid aneurysm of the scalp. Singapore Med J 48:268-269, 2007

6. Dabus G, Pizzolato R, Lin E, Kreusch A, Linfante I: Endovascular treatment for traumatic scalp arteriovenous fistulas: Results with Onyx embolization. J Neurointerv Surg 6:405-408, 2014, Epub 2013 Jun 20

7. Dalyai RT, Schirmer CM, Malek AM: Transvenous balloonprotected embolization of a scalp arteriovenous fistula using Onyx liquid embolic. Acta Neurochir (Wien) 153:1285-1290, 2011

8. Davis AJ, Nelson PK: Arteriovenous fistula of the scalp secondary to punch autograft hair transplantation: Angioarchitecture, histopathology, and endovascular and surgical therapy. Plast Reconstr Surg 100:242-249, 1997

9. Dogan S, Cinar C, Demirpolat G, Memis A: Endovascular treatment of AVF after hair transplantation. Cardiovasc Intervent Radiol 2:128-130, 2008

10. Elkin DC: Cirsoid aneurysm of the scalp with the report of an advanced case. Ann Surg 80:332-340, 1924 
11. El Shazly AA, Saoud KM: Results of surgical excision of cirsoid aneurysm of the scalp without preoperative interventions. Asian J Neurosurg 7:191-196, 2012

12. Fisher-Jeffes ND, Domingo $Z$, Madden $M$, De Villiers JC: Arteriovenous malformations of the scalp. Neurosurgery 36:656-660; discussion 660, 1995

13. Fukuta K, Smith RJ, Jackson IT: Arteriovenous fistula formation after punch graft hair transplantation in the frontal region. Plast Reconstr Surg 93:587-589, 1994

14. Gupta AK, Purkayastha S, Bodhey NK, Kapilamoorthy TR, Krishnamoorthy T, Kesavadas C, Thomas B: Endovascular treatment of scalp cirsoid aneurysms. Neurol India 56: 167-172, 2008

15. Gurkanlar D, Gonul M, Solmaz I, Gonul E: Cirsoid aneurysms of the scalp. Neurosurg Rev 29:208-212, 2006

16. Hendrix LE, Meyer GA, Erickson SJ: Cirsoid aneurysm treatment by percutaneous injection of sodium tetradecyl sulfate. Surg Neurol 46:557-560; discussion 560-561, 1996

17. Hyshaw C, Di Tullio M, Renaudin J: Superficial temporal arteriovenous Fistula. Surg Neurol 12:46-48, 1979

18. Jimenez JP, Goree JA: Traumatic arteriovenous fistula of the superficial temporal artery: Report of a case. Am J Roentgenol Radium Ther Nucl Med 106:279-281, 1969

19. Komiyama M, Nishikawa M, Kitano S, Sakamoto H, Imai K, Tsujiguchi K, Mizuno T: Non-traumatic arteriovenous fistulas of the scalp treated by a combination of embolization and surgical removal. Neurol Med Chir (Tokyo) 36:162-165, 1996

20. Kumar A, Ahuja CK, Khandelwal N, Bakshi JB: Cirsoid aneurysm of the right pre-auricular region: An unusual cause of tinnitus managed by endovascular glue embolisation. J Laryngol Otol 26:923-927, 2012

21. Li F, Zhu S, Liu Y, Chen Y, Chi L, Chen G, Zhang J, Qu F:Traumatic arteriovenous fistula of the superficial temporal artery. J Clin Neurosci 14:595-600, 2007

22. Luessenhop AJ: Cirsoid aneurysms of the scalp. J Neurosurg 75:167, 1991

23. Mathis JM, DeNardo AJ, Jensen ME, Lin KY, Dion JE: Arteriovenous fistula of the scalp after hair transplantation treated by endovascular embolization. Ann Plast Surg 33: 633-637, 1994
24. Morioka T, Nishio S, Hikita T: Traumatic arteriovenous fistula of the scalp at the site of previous craniotomy. Surg Neurol 30:406-407, 1988

25. Muthukumar N, Rajagopal V, Manoharan AV, Durairaj N: Surgical management of cirsoid aneurysms. Acta Neurochir (Wien) 144:349-356, 2002

26. Nagasaka S, Fukushima T, Goto K, Ohjimi H, Iwabuchi S, Maehara F: Treatment of scalp arteriovenous malformations. Neurosurgery 38:671-677, 1996

27. Nishimura T, Kubota S: A case of congenital AVM in temporoparietal muscle. No Shinkei Geka 24:277-280, 1996

28. Shinoda J, Iwai T, Morita T, Miwa Y, Takada M, Sakai N, Yamada $\mathrm{H}$ : Traumatic arteriovenous fistula of the scalp--report of two cases and review of the literature in Japan. Neurol Med Chir (Tokyo) 25:55-60,1985

29. Sugrue M, McCollum P, O'Driscoll K, Feeley M, Shanik DG, Moore DJ: Congenital arteriovenous malformation of the scalp with high output cardiac failure: A case report. Ann Vasc Surg 3:387-388,1989

30. Tanaka T, Hasegawa Y, Kanki T, Hayashi J, Ui K, Usami S, Abe T: Combination of intravascular surgery and surgical operation for occipital subcutaneous arteriovenous fistula in a patient with neurofibromatosis type I. No Shinkei Geka 30:309-313, 2002

31. Tauro LF, Suhith G, Shetty P, Rao D: Cirsoid aneurysm of scalp. J Neurosci Rural Pract 3:95-96, 2012

32. Tokunaga K, Kusaka N, Nakashima H, Ohmoto T: A case of a scalp arteriovenous fistula associated with Rendu-OslerWeber disease treated by direct percutaneous embolization. No Shinkei Geka 28:447-452, 2000

33. Whiteside OJ, Monksfield P, Steventon NB, Byrne J, Burton MJ: Endovascular embolization of a traumatic arteriovenous fistula of the superficial temporal artery. J Laryngol Otol 119:322-324, 2005

34. Yokouchi T, Iwabuchi S, Tomiyama A, Samejima H, Ogata N, Goto K: Embolization of scalp AVF. Interv Neuroradiol 5 Suppl 1:121-126, 1999 